\title{
CHARACTERISATION OF AN UNUSUAL BACTERIUM ISOLATED FROM GENITAL ULCERS
}

\author{
J.-P. Ursi, E. Van DycK*, R. C. Ballard $\dagger$, W. Jacob, \\ P. PIOT* AND A. Z. MEHEUS

\begin{abstract}
Microbiology Laboratory, University of Antwerp and * Institute for Tropical Medicine, Antwerp, Belgium, and $\dagger$ the South African Institute for Medical Research, Johannesburg, South Africa
\end{abstract}

\begin{abstract}
SUMmaRY. The preliminary characterisation of an unusual gram-negative bacillus isolated from genital ulcers in Swaziland is reported. Like Haemophilus ducreyi, it is an oxidase positive, nitrate-reductase-positive gram-negative rod that forms streptobacillary chains in some circumstances; it was therefore called the "ducreyi-like bacterium" (DLB). Distinguishing features of DLB are production of $\alpha$-haemolysis on horse-blood agar, stimulation of growth by a microaerophilic atmosphere and by a factor produced by Staphylococcus aureus, a strongly positive porphyrin test, and a remarkable ability to undergo autolysis. DLB has a guanine + cytosine value of $c .50 \mathrm{~mole} \%$ but it cannot be classified, even at the genus level, until more taxonomic data are obtained.
\end{abstract}

\section{INTRODUCTION}

Haemophilus ducreyi is an important cause of genital ulcers in many developing countries. A reliable serological diagnostic test is not available and microscopic examination of gram-stained smears from lesions is useful in only a limited number of cases (Kampmeier, 1977). A definitive diagnosis of chancroid can be made only by isolation and identification of $H$. ducreyi from the lesions. However, this may be complicated by the presence of bacteria that can be confused with $H$. ducreyi (Aoki et al., 1952; Leibovitz, 1954; Deacon et al., 1956; Kilian, 1976) and other micro-organisms of unknown pathological significance (Chapel et al., 1978). During a recent study of genital ulcers in Swaziland, an unusual gram-negative bacillus was isolated from several lesions that clinically resembled chancroid on culture media used for isolation of $H$. ducreyi. Morphologically these isolates resembled $H$. ducreyi and they have, therefore, been called ducreyi-like bacteria (DLB). In this paper the preliminary characterisation of these isolates is reported.

\section{MATERIALS AND METHODS}

Patients. One hundred and fifty-five consecutive patients with genital ulcers attending the

Received 1 Jun. 1981; accepted 24 Jul. 1981.

Reprints requests to Dr J.-P. Ursi, Laboratorium voor Microbiologie, Akademisch Ziekenhuis Antwerpen, Wilrijkstraat 10, B-2520 Edegem, Belgium. 
clinic for sexually transmitted diseases at the Outpatients' Department of Mbabane General Hospital, Mbabane, Swaziland, were included in the study.

Primary isolation of $D L B$. After thorough cleaning of the genital ulcer with sterile physiological saline, material was collected from its base with a calcium alginate swab (Inolex, code 60-50-15) and seeded directly on to two solid culture media: (i) Diagnostic Sensitivity Test (DST) Agar (Oxoid) with horse blood 5\%, IsoVitaleX (Baltimore Biochemical Laboratories) $1 \%$ ) and vancomycin $3 \mu \mathrm{g} / \mathrm{ml}$; and (ii) Hammond's medium which consists of Gonococcus (GC) Agar (Difco), with haemoglobin (Difco) $1 \%$, IsoVitaleX $1 \%$ and vancomycin $3 \mu \mathrm{g} / \mathrm{ml}$ (Hammond et al., 1978). All plates were incubated at $35^{\circ} \mathrm{C}$ in candle jars and examined daily for 10 days. Isolates were subcultured every $72 \mathrm{~h}$ on to the medium originally used for primary isolation and they were lyophilised for storage and transport after less than 15 passages.

Haemophilus ducreyi. Eight strains of $H$. ducreyi, for comparative studies, were kindly provided by the Pasteur Institute, Paris, Professor A. Ronald, Winnipeg and Dr W. Sturm, Amsterdam.

Growth and morphological characteristics. Anaerobic and microaerophilic conditions were obtained with hydrogen and carbon dioxide generators (GasPak, BBL) in GasPak jars (BBL) with and without catalyst. Requirement for $\mathrm{X}$ and $\mathrm{V}$ factors were determined with impregnated filter-paper strips (BBL) on Columbia Agar (BBL). Enhancement of growth by staphylococcus filtrate (SF) was studied on DST Agar containing horse blood $5 \%$ with and without SF $10 \%$. SF was prepared by incubating Staphylococcus aureus strain ATCC 25923 in Trypticase Soy Broth (Bio-Mérieux, Marcy-l'Etoile, France) at $37^{\circ} \mathrm{C}$ for $48 \mathrm{~h}$ with vigorous stirring; cultures were centrifuged at $1500 \mathrm{~g}$ for $1 \mathrm{~h}$ and the supernate was sterilised by membrane filtration (pore size $0.22 \mu \mathrm{m}$ ). The presence of streptobacillary chains was determined by examination of gram-stained smears of fluid that had condensed on DST-Agar slopes after incubation for 24 and $48 \mathrm{~h}$ at $35^{\circ} \mathrm{C}$ in a microaerophilic atmosphere.

Biochemical tests. The ability of strains to produce hydrogen sulphide was tested with lead acetate paper strips (Merck Chemicals), and National Collection of Type Cultures (NCTC) micromethods (Clarke and Cowan, 1952; Shaw and Clarke, 1955) were used in tests for reduction of nitrate and production of indole, urease, phenylalanine deaminase, lysine and ornithine decarboxylase and arginine dihydrolase. Carbohydrate fermentation reactions were tested by the method of Brown (1974), the oxidase reaction by Kovács's method (Kovács, 1956) and porphyrin production by the technique of Kilian (1974). The ability of strains to produce $\beta$-galactosidase was tested with paper disks containing o-nitrophenyl- $\beta$-D-glycopyranoside (ONPG discs, Bio-Mérieux; Le Minor and Ben Hamida, 1962) and alkaline phosphatase by the method of White and Pickett (1953).

Preparation of bacterial DNA and measurement of base composition. Large quantities of DLB were grown in petri dishes on DST agar with horse blood $5 \%$ and SF $10 \%$. Cultures were incubated at $35^{\circ} \mathrm{C}$ in a microaerophilic atmosphere for $24 \mathrm{~h}$ before removal of bacterial colonies. Bacterial DNA was prepared by the method of Marmur (1961). The base composition of the total genome DNA was measured by the thermal denaturation method (De Ley and Van Muylem, 1963) and calculated by the equation of Marmur and Doty (1962) as modified by De Ley (1970).

Electron microscopy. DLB were grown on Columbia Agar with horse blood $5 \%$ and Biosate Peptone (BBL) $3 \%$. After incubation at $35^{\circ} \mathrm{C}$ in a microaerophilic atmosphere for $18 \mathrm{~h}$ intact bacterial colonies with small blocks of underlying agar were cut. These were fixed by the method of Ryter and Kellenberger (1958) and embedded by the method of Spurr (1969). Thin sections $(50 \mathrm{~nm})$ were stained with uranyl acetate and lead acetate and examined at $80 \mathrm{kV}$ accelerating voltage in a Jeol electron microscope.

\section{RESULTS}

DLB were isolated from the genital ulcers of 25 of 155 patients $(16 \cdot 1 \%)$. Nineteen isolates survived transport to Belgium.

DLB were isolated on both media used for primary isolation; 15 of the surviving strains were initially isolated on the supplemented DST agar, while 
another four strains were isolated on Hammond's medium. On both media DLB appeared as small translucent, punctiform colonies after incubation for 2-7 days.

At the beginning of these studies, two factors were found that enhanced the growth of these organisms: (i) a microaerophilic atmosphere which gave better results than either air plus $5 \% \mathrm{CO}_{2}$ or a strictly anaerobic atmosphere, and (ii) the presence of contaminating colonies of $S$. aureus. This second factor led to the preparation of $\mathrm{SF}$, which was added to the agar medium in various amounts. An SF concentration of $10 \%$ produced optimal growth for all strains.

The growth characteristics of DLB and $H$. ducreyi are shown in table I. Although they differ in many respects, confusion may occur because of the common site of primary isolation and the frequent finding of gram-negative bacilli in smears from genital ulcers. After incubation for $48 \mathrm{~h}$, the colonies of DLB on Columbia Agar with horse blood $5 \%$ were smooth and translucent, produced a yellow pigment and exhibited a discrete $\alpha$-haemolysis. In contrast, colonies of $H$. ducreyi were opaque, grey, rough and $\beta$-haemolytic. Unlike $H$. ducreyi, DLB did not require $\mathrm{V}$ factor for growth, indicating that the growth factor in SF is not nicotinamide dinucleotide. The growth factor in SF was heat stable $\left(121^{\circ} \mathrm{C}\right.$ for $\left.1 \mathrm{~h}\right)$, unaffected by trypsin $\left(0.5 \%\right.$ for $30 \mathrm{~min}$ at $\left.37^{\circ} \mathrm{C}\right)$ and may be present in Columbia Agar (BBL) with horse blood $5 \%$, because growth was almost maximal on this medium and the addition of SF $10 \%$ resulted in only slight enhancement of growth. Biosate peptone, a major constituent of BBL Columbia Agar, at a final concentration of $4 \%$, enhanced growth significantly. Moreover, DLB did not require $\mathrm{X}$ factor for growth, a finding that was confirmed by a strongly positive porphyrin test. $H$. ducreyi was consistently negative in the porphyrin test.

Both $H$. ducreyi and DLB formed streptobacillary chains, but those of DLB were much shorter than those of $H$.ducreyi. However, the most striking feature of DLB was its ability to undergo autolysis. Gram-stained smears of 48-h cultures showed almost exclusively lysed bacterial cells (fig. 1b) and even

TABLE I

Growth characteristics of DLB (8 strains) and Haemophilus ducreyi (19 strains)

\begin{tabular}{|c|c|c|}
\hline \multirow[b]{2}{*}{ Character } & \multicolumn{2}{|c|}{ Reaction or property of } \\
\hline & Haemophilus ducreyi & DLB \\
\hline Morphology of colonies & $\begin{array}{l}\text { Grey, opalescent, } \\
\text { pleomorphic, rough }\end{array}$ & $\begin{array}{l}\text { Translucent, } \\
\text { homogeneous, } \\
\text { smooth. }\end{array}$ \\
\hline Chain formation & Long chains & Short chains \\
\hline $\begin{array}{l}\text { Motility } \\
\text { Maximal growth after }\end{array}$ & $72 \mathrm{~h}$ & $48 \mathrm{~h}$ \\
\hline Lysis after $48 \mathrm{~h}$ & & + \\
\hline $\begin{array}{l}\text { Favourable atmosphere } \\
\text { Temperature range for growth }\end{array}$ & $\begin{array}{l}\text { Increased } \mathrm{CO}_{2}(5 \%) \\
32-36^{\circ} \mathrm{C}\end{array}$ & $\begin{array}{l}\text { Microaerophilic } \\
25-42^{\circ} \mathrm{C}\end{array}$ \\
\hline V-factor requirement & - & \\
\hline $\mathrm{X}$-factor requirement & + & - \\
\hline SF requirement & - & + \\
\hline
\end{tabular}

$\mathrm{DLB}=$ ducreyi-like bacteria; $\mathrm{SF}=$ staphylococcus filtrate; $-=$ all strains negative; $+=$ all strains positive 

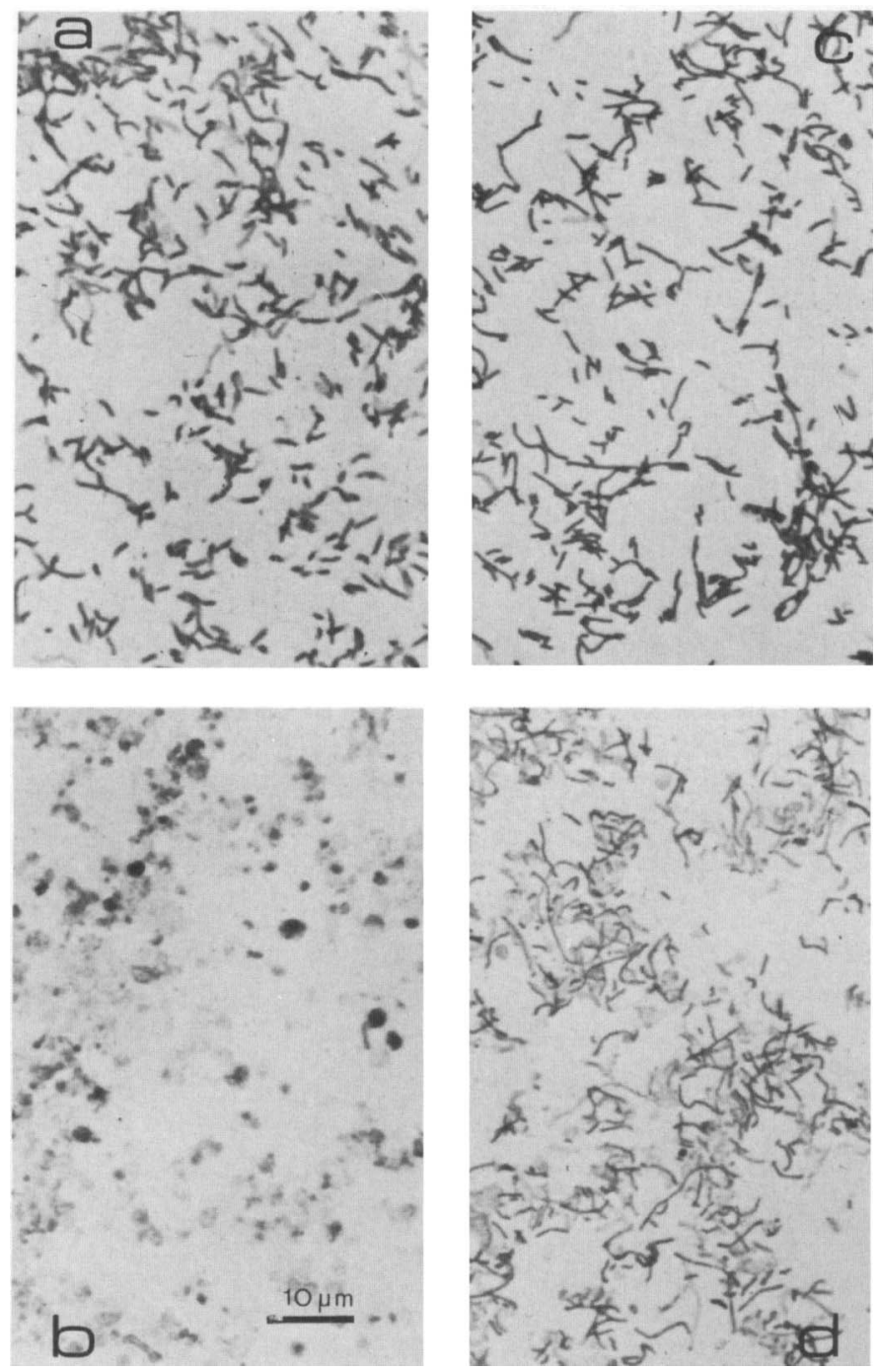

Fig. 1.-Gram-stained smears of DLB after growth on: a. Columbia blood agar after $24 \mathrm{~h}$; b. Columbia blood agar after 48; c. Columbia blood agar with Biosate Peptone 4\% after $24 \mathrm{~h}$; d. Columbia blood agar with $4 \%$ Biosate peptone after $48 \mathrm{~h}$.

after $24 \mathrm{~h}$, many bacteria appeared swollen, with indistinct borders (fig. 1a). Between 24 and $48 \mathrm{~h}$, the number of viable organisms consistently dropped by a factor of $c .10^{3}$. This autolysis could be prevented in part by raising the concentration of Biosate Peptone in the medium to $4 \%$. After incubation for $24 \mathrm{~h}$ the bacteria appeared healthier, although still rather pleomorphic (fig. 1c), and this appearance was maintained at $48 \mathrm{~h}$ although some bacteria had lysed (fig. 1d).

Attempts to grow DLB in liquid media were disappointing. In Columbia Broth with horse blood $5 \%$, saponin $1 \%$ and Biosate Peptone $3 \%$, the viable 


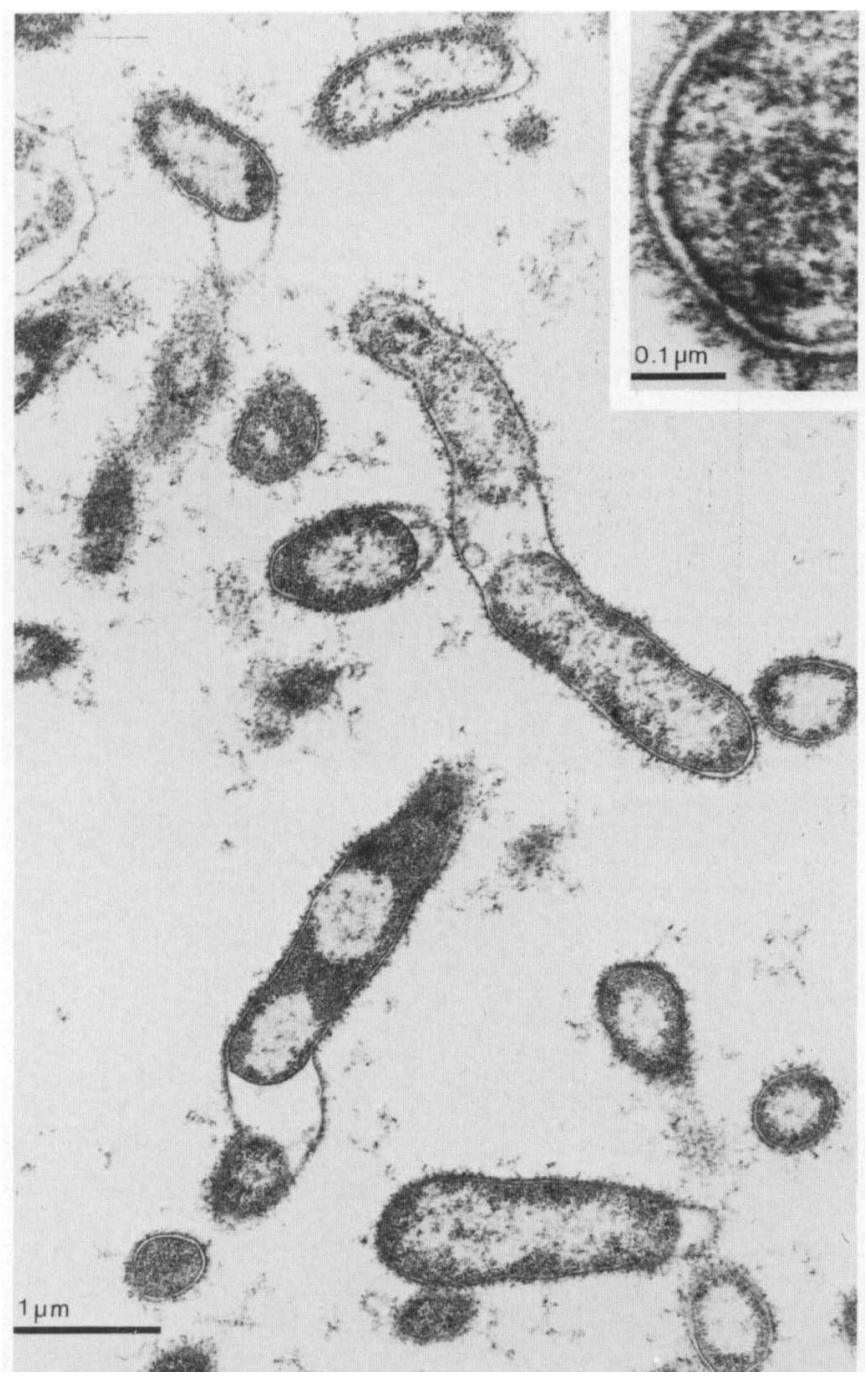

Fig. 2.-Ultra-thin section through colony of DLB showing bacteria that contain several membraneenclosed cytoplasmic 'packages' within one cell-wall structure. Inset: detail of cell-wall structure.

count increased from $10^{4} \mathrm{cfu} / \mathrm{ml}$ to $5 \times 10^{7} \mathrm{cfu} / \mathrm{ml}$ after $24 \mathrm{~h}$ but declined rapidly on further incubation.

The spontaneous lysis of DLB made electronmicroscopic studies difficult and early attempts yielded pictures of empty shells. However, when the bacteria were grown on media supplemented with Biosate Peptone $4 \%$, better results were obtained (fig. 2). The cell wall is characteristic of most gram-negative organisms; an "outer membrane" is separated from the cytoplasmic membrane by a more electron-translucent zone. There was no evidence of cell division. However, many cells showed expansions of the cytoplasmic membrane, delineating vast compartments within the cell. Some cells contained two of these structures, but there was no associated pinching of 
TABLE II

Biochemical characteristics of 19 strains of DLB

\begin{tabular}{|c|c|c|c|}
\hline Test & Result & Test & Result \\
\hline $\begin{array}{l}\text { Production of: } \\
\text { indole } \\
\text { urease } \\
\text { porphyrin } \\
\text { hydrogen sulphide } \\
\text { catalase } \\
\text { oxidase } \\
\beta \text { galactosidase } \\
\beta \text { lactamase } \\
\text { phenylalanine deaminase } \\
\text { alkaline phosphatase } \\
\text { lysine decarboxylase }\end{array}$ & $\begin{array}{c}- \\
- \\
++ \\
+ \\
+ \\
+ \\
- \\
- \\
- \\
- \\
-\end{array}$ & $\begin{array}{l}\text { Production of: } \\
\text { arginine dihydrolase } \\
\text { ornithine decarboxylase } \\
\text { Fermentation of: } \\
\text { glucose } \\
\text { xylose } \\
\text { lactose } \\
\text { sucrose } \\
\text { mannitol } \\
\text { deoxyribose } \\
\text { Reduction of nitrate }\end{array}$ & $\begin{array}{l}- \\
+ \\
- \\
- \\
- \\
- \\
+\end{array}$ \\
\hline
\end{tabular}

$-=$ All strains negative; $+=$ all strains positive; $++=$ all strains strongly positive $;+1-=$ variable $(66 \cdot 6 \%$ of 39 tests for ornithine decarboxylase and $77.9 \%$ of 77 tests for ornithine decarboxylase were positive; all strains gave at least one positive result in each test)

the cell wall. The significance of this compartmentation is not evident. In view of the spontaneous lysis of these bacteria, many lysed cultures were examined for evidence of infection with bacteriophages. No such evidence was obtained.

The biochemical characteristics of DLB shown in table II. The oxidase reaction was slowly positive, and production of hydrogen sulphide could usually be demonstrated after 2-3 days. The porphyrin test was strongly positive after $4 \mathrm{~h}$ and nitrate reduction was weakly positive. Tests for arginine dihydrolase and ornithine decarboxylase were usually positive, but the results were not uniformly reproducible.

The extraction of DNA from DLB proved difficult, probably as a result of the tendency of the bacteria to undergo spontaneous lysis. The DNA-base composition of two strains was determined; they had guanine + cytosine values of 49.6 and $50.6 \mathrm{~mol} \%$.

\section{Discussion}

Although on morphological grounds DLB appear to belong to the genus Haemophilus, they do not meet the classical criteria established for this genus (requirement of X and V factors), nor the criteria proposed by Kilian (1976), i.e., reduction of nitrate and production of alkaline phosphatase. Moreover, the DNA-base composition of DLB (guanine+cytosine $c .50 \mathrm{~mol} \%$ ) differs from that for Haemophilus spp. (38-42 mol\%; Zinnemann and Biberstein, 1974). Classification of DLB at the genus level remains speculative, and more comparative data are required. However, the uniformity of growth, morphological and biochemical characteristics of the DLB isolates tested indicates that they are a homogenous group of bacteria that could belong to a single species.

All the strains described in this study were isolated from genital ulcers of presumed venereal origin and more investigation of the pathogenicity of these organisms and their possible sexual transmission is required before an aetiological role can be assigned. However, because DLB have been isolated from a large number of genital ulcers on a selective medium previously used for 
isolation of $H$. ducreyi, it is important that they be differentiated from $H$. ducreyi.

We wish to thank Professors S. R. Pattyn, J. De Ley and H. J. Koornhof for their helpful advice, comments and encouragement, and Dr J. Colaert, Mrs J. Verhoeven and Mr P. De Vos for their specialised services.

\section{REFERENCES}

Aoki, Y., Kawai, K., Nakamura, T., Shiraki, M. and Harada, H. 1952. An organism resembling Hemophilus ducreyi; a species found at a high rate in genitals of prostitutes in the Sasebo area. Yokohama med. Bull., 3, 310.

Brown, W. J. 1974. Modification of the rapid fermentation test for Neisseria gonorrhoeae. Appl. Microbiol., 27, 1027.

Chapel, T., Brown, W. J., JefFries, C. And Stewart, J. A. 1978. The microbiological flora of penile ulcerations. J. infect. Dis., 137, 50.

Clarke, P. H. and Cowan, S. T. 1952. Biochemical methods for bacteriology. J. gen. Microbiol., 6, 187.

Deacon, W. E., Albritton, D. C., Olansky, S. and Kaplan, W. 1956. V.D.R.L. chancroid studies. I. A simple procedure for the isolation and identification of Haemophilus ducreyi. J. invest. Derm., 26, 399.

DE LEY, J. 1970. Reexamination of the association between melting point, buoyant density and chemical base composition of deoxyribonucleic acid. J. Bact., 101, 738.

De Ley, J. AND van Muylem, J. 1963. Some applications of deoxyribonucleic acid base composition in bacterial taxonomy. Antonie van Leeuwenhoek, 29, 344.

Hammond, G. W., Lian, C. J., Wilt, J. C. and Ronald, A. R. 1978. Comparison of specimen collection and laboratory techniques for the isolation of Haemophilus ducreyi. J. clin Microbiol., 7, 39.

KAMPMEIER, R. H. 1977. Chancroid. In Infectious diseases, 2nd ed., edited by P. D. Hoeprich, Harper \& Row, Hagerstown, Md, p. 507.

Kilian, M. 1974. A rapid method for the differentiation of Haemophilus strains. The porphyrin test. Acta path. microbiol. scand. B, 82, 835 .

Kilian, M. 1976. A taxonomic study of the genus Haemophilus, with the proposal of a new species. J. gen. Microbiol., 93, 9.

Kovács, N. 1956. Identification of Pseudomonas pyocyanea by the oxidase reaction. Nature, Lond., 178, 703.

LEIBOVITZ, A. 1954. An outbreak of pyogenic penile ulcers associated with a microaerophilic streptococcus resembling Haemophilus ducreyi. Am. J. Syph. Neurol., 38, 203.

LE MinOR, L. AND BEN HAMIDA, F. 1962. Avantages de la recherche de la $\beta$-galactosidase sur celle de la fermentation du lactose en milieu complexe dans le diagnostic bactériologique, en particulier des Enterobacteriaceae. Annls Inst. Pasteur, Paris, 102, 267.

MARMUR, J. A. 1961. A procedure for the isolation of deoxyribonucleic acid from microorganisms. J. molec. Biol., 3, 208.

MARMur, J. AND DotY, P. 1962. Determination of the base composition of deoxyribonucleic acid from its thermal denaturation temperature. J. Molec. Biol., 5, 109.

Ryter, A. AND Kellenberger, E. 1958. Etude au microscope électronique de plasmas contenant de l'acide désoxyribonucléique. 1. Les nucléotides des bactéries en croissance active. Z. Naturf., 13B, 597.

Shaw, C. and Clarke, P. H. 1955. Biochemical classification of Proteus and Providence cultures. J. gen. Microbiol., 13, 155.

SPURR, A. R. 1969. A low-viscosity epoxy resin embedding medium for electron microscopy. $J$. Ultrastruct. Res., 26, 31.

White, M. L. AND PiCKeTt, M. J. 1953. A rapid phosphatase test for Micrococcus pyogenes var. aureus for detection of potentially pathogenic strains. Am J. clin. Path., 23, 1181.

ZinNeman, K. AND Bibersteon, E. L. 1974. Genus Haemophilus. In Bergey's manual of determinative bacteriology, 8th ed., edited by R. E. Buchanan and N. E. Gibbons, Williams \& Wilkins, Baltimore, p. 364. 